\title{
Construction and Comparison of Relationship Models of Urban Tourism Development
}

\author{
Shwu-Ing $\mathrm{Wu}^{1}$ \\ ${ }^{1}$ Department of Business Administration, National Chin-Yi University of Technology, Taiwan, R.O.C. \\ Correspondence: Shwu-Ing Wu, Department of Business Administration, National Chin-Yi University of \\ Technology, No.57, Section 2, Zhongshan Road, Taiping, Taichung, Taiwan, R.O.C. Tel: 886-4-2392-4505. \\ E-mail:wusi@ncut.edu.tw
}

$\begin{array}{lc}\text { Received: April 23, } 2015 & \text { Accepted: May 6, } 2015 \quad \text { Online Published: July 30, } 2015 \\ \text { doi:10.5539/ijms.v7n4p9 } & \text { URL: http://dx.doi.org/10.5539/ijms.v7n4p9 }\end{array}$

This research was made possible through the support of the Ministry of Science and Technology of Republic of China, Taiwan, under project (MOST 103 - 2410 - H - 167 - 005 -).

\begin{abstract}
Tourism image and innovation marketing of cities are critical in tourism strategy and urban development since they demonstrate the regional characteristics and images. By image promotion and innovation marketing, we can construct tourists' attitude and influence their comments and travel intention in the regions. This study focuses on Taipei, Taichung, and Kaohsiung in Taiwan and explores the effects of tourism image and innovation marketing strategy of cities on tourists' experiential value, satisfaction and loyalty in different regions and the difference of intensity in order to explore the characteristics of the cities.

According to investigation by 750 questionnaires, tourism image and innovation marketing of Taipei, Taichung, and Kaohsiung have significantly different effects on tourists' experiential effect. It shows the difference of different cities. In addition, (1) tourism image of three cities significantly and positively influences experiential value; (2) experiential value of three cities significantly and positively influences satisfaction; (3) satisfaction with three cities significantly and positively influences loyalty; (4) innovation marketing strategy of Taipei and Taichung significantly and positively influences experiential value, except for Kaohsiung; (5) tourism image of Taichung significantly and positively influences loyalty, except for the other two cities. The findings can serve as reference for decision making of urban development and operational strategy of the cities.
\end{abstract}

Keywords: tourism image, innovation marketing, experiential value, satisfaction, loyalty

\section{Introduction}

Tourism industry is one of the most potential industries in the $21^{\text {st }}$ century. In order to attract the tourists, the cities in the world attempt to reinforce development of local tourism industry by investment in construction or holding different activities. Tourism is the intangible asset of a country and it is the service of sensory experience. Successful tourism industry will enhance local employment and incomes and it is treated as the drive of regional development. It not only reinforces local industry and the profits, but also enhances inter-regional cultural exchange and cooperation (Chen \& Tsai, 2007). Key factors of tourists' selection of spots are local tourism image and innovation marketing (Smith \& Colgate, 2007).

Tourists obtain images of tourist sports from news reports, magazines and TV reports. The perception and impression caused by information will indirectly become tourists' tourism image (Gunn \& Var, 2002). By unique recreational facilities and natural resources, we can create regional tourism image to attract tourists and enhance tourists' image and comments. When tourists' expectation matches the content of the places, it means that the places meet the tourists' expected benefits (Mayo \& Jarvis, 1981).

Tourists tend to select the impressive scenic areas with positive images as the travel destinations (Chaudhary, 2000). Thus, tourism image is extremely important for urban development. It not only influences tourists' selection of destinations, but also affects their decision making. It is the important issue of tourism marketing research and the measure for global marketing (Castro, Armario, \& Ruiz, 2007; Hosany, Ekinci, \& Uysal, 2006). 
People require the enhancement of tourism quality and they pursue new and changeable travel model instead of the traditional travel mode. Hence, marketing strategies of different cities must be more innovative. Creative travel model or activities different from the past will be more attractive for tourists. Thus, for the tourists, diverse methods of innovation marketing are the keys to attract tourists.

It is insufficient to learn tourists' experiential value simply by past experience since tourists' needs change all the time (Flint, Woodruff, \& Gardial, 2002). In order to meet customers' needs, the cities should continuously hold innovation marketing activities in order to construct attractive urban image. For instance, they must develop activities with tourists to create experiential value and enhance tourists' satisfaction since tourists' experiential value is significantly influenced by tourism image and innovation marketing and considerably affects tourists' satisfaction (Vargo \& Lusch, 2006).

When tourists perceive unexpected leisure experience, they will have higher satisfaction and revisit intention (Ross, 1993). Hence, consumers' experiential value positively influences satisfaction (Wu \& Zheng, 2014). Experiential value can create appropriate experience and affection to tourists and it is the moderator between experience and satisfaction. Tourists will first recognize the internal perception in the experience and it influences their loyalty to the tourist spots (Smith \& Colgate, 2007). If tourists' satisfaction can be higher than their expected value, it will enhance their preference to the areas and future behavioral intention (Carpenter, 2009).

Based on the above, creation of positive tourism image and innovation marketing are the key factors of urban tourism development. In order to obtain advantages in severe competition of the cities, we must establish positive urban image and adopt innovation marketing to enhance positive image for tourists. Although many literatures have studied urban tourism development, few of them explored the previous dimensions, analyzed and compared different cities. Hence, this study focuses on Taipei, Taichung, and Kaohsiung and treats the tourists of Taipei, Taichung, and Kaohsiung as subjects in order to recognize their views toward tourism image of three big cities in Taiwan, innovation marketing, experiential value, satisfaction and loyalty in order to explore the effects of tourism image and innovation marketing of the cities on tourists' experiential effect.

According to the previous research background and motive, main purposes of this study is to explore effects of tourism image and innovation marketing of 3 cities on tourists' experiential value, satisfaction and loyalty. Thus, this study investigates tourists who have visited Taipei, Taichung, and Kaohsiung and proposes analysis and suggestion from perspective of tourists in order to provide useful information for strategic construction of urban marketing.

\section{Literature Review}

\subsection{Tourism Image}

Tourism image is individuals' cognition and affective comments constructed by their knowledge, impression, imagination and affection toward the tourist spots (Martin \& del Bosque, 2008); it also means the image of travel destinations for tourists and it is the pre-image for tourists (Fakeye \& Crompton, 1991); it is tourists' expectation toward the spots and it helps them have travel decision making (Leisen, 2001). Prebensen (2007) suggested that tourism image is the base to construct competitive and successful travel destinations. By tourists' tourism image, we can recognize their views or thoughts about the spots and reasons to properly develop local tourism image and attraction (Ritchie \& Crouch, 2000).

Echtner \& Ritchie (1993) divided tourism image into comfortable/safe, interesting/adventurous, natural state, travel facilities, entertaining atmosphere/climate, cultural difference, low prices and without language barriers. Stepchenkova \& Morrison (2008) classified tourism image into traditional travel, basic facilities, niche travel, safety, history, food and culture, service, adventure and adults with families. Martin \& del Bosque (2008) divided tourism image into basic facilities and social \& economic environment, atmosphere, natural environment, affective image and cultural environment. Royo-Vela (2009) measured tourism image by historic and cultural relics, atmosphere, tourist/customer service, building, history \& art, shopping and food, tourist management, tourist supply and infrastructure.

Since Taipei, Taichung, and Kaohsiung all have historic cultural relics, modern construction, natural scenery and local snacks, this study generalizes the previous scholars' classification of tourism image and divides tourism image into natural ecology, culture and history, urban environment and local characteristics as the items to measure tourism image.

\subsection{Innovation Marketing}

Innovation is the development of new products or services, manufacturing technique, management system, 
organizational structure, plan or strategy (Chen \& Liu, 2005); it means to use new knowledge (technology or market knowledge), combine invention and commercialization and offering of new service or product for customers (Afuah, 2003). Certo (2003) defined innovation as "the process to transform useful ideas to useful products, services or methods."

Although the final product of innovation is associated with "new", the process of innovation is related to "old" (Smith, 1998). For instance, in creation of new service, we must transform old service into new one matching consumers' needs. It is service innovation. Innovation can improve product or service quality, enhance corporate image, increase customer loyalty and attract potential customers (Ottenbacher \& Gnoth, 2005).

Betz (1998) classified innovation into product innovation, procedure innovation and service innovation. Johannessen et al. (2001) suggested that innovation includes new products, new services, new methods or production (manufacturing/technological innovation), new market, new supply sources and new organizational methods. Catherine \& Pervaiz (2004) divided innovation into five dimensions: product, market, procedure, behavior and strategy. Xi \& Fang (2005) divided innovation into product innovation, manufacturing innovation, resource distribution innovation, organizational innovation and marketing innovation.

This study focuses on cities instead of products. Therefore, based on the above, we generalize physical construction innovation and activity \& procedure innovation to measure the content of urban innovation marketing.

\subsection{Experiential Value}

Experiential value is the attitude toward products and preference to consumption performance in the interaction of consumption when we encourage consumers to accomplish the consumption goals (Mathwick, Malhotra, \& Rigdon, 2002). Gallarza \& Saura (2006) suggested that experiential value is the factor which directly influences customer satisfaction. Excellent service can decide customers' experiential value and create appropriate experience and feelings to customers. Therefore, tourists pay attention not only to goods, service, novelty and brand, but also to final experience. With more sensory experience, tourists will have unforgettable memory and pleasant feelings (Pine \& Gilmore, 2003). Hence, the participants will cherish the participation. When the experience ends, they will remember the value created. It shows the importance of experiential value.

Sweeney \& Soutar (2001) divided experiential value into affection, society, price and quality. Ulaga (2003) suggested that experiential value includes affection, function and dynamics. Yang, Wu \& Wang (2009) classified experiential value into utilitarian value and hedonic value. Williams \& Soutar (2009) measured experiential value by function, affection, society, knowledge/novelty and money value. Schmitt (1999) developed one scale to measure sense, affection, thoughts, action and association. They can be the dimensions of travel experiential value.

Thus, based on concepts of experiential value proposed by the previous scholars, this study generalizes affective experience, sensory experience and quality experience as the items to measure experiential value.

\subsection{Satisfaction}

Satisfaction is individuals' total satisfaction with products or services (Hellier et al., 2003); it is the experience of attributes of all goods and services (Lee, Lee, \& Wicks, 2004). Baker \& Crompton (2000) suggested that satisfaction is tourists' real experience after the activities and it is their feelings after interacting with the destinations. It is tourists' reaction and judgment of satisfaction (Kim, Park, \& Jeong, 2004).

Pappu \& Quester (2006) indicated that satisfaction means the match between product/service and customers' needs and expectation. Therefore, satisfaction is associated with expectation before the trip and experience after the trip. Tourists are more satisfied when the experience matches the expectation (Reisinger \& Turner, 2003). Therefore, satisfaction is tourists' overall satisfaction after visiting certain area (Cole \& Scott, 2004).

Lee, Graefe \& Burns (2004) suggested that measurement of tourists' satisfaction includes total pleasure, intention to pay and dissatisfaction. According to Yoon \& Uysal (2005), measurement on tourists' satisfaction means to compare tourists' satisfaction with expectation, tourism value with past travel experience.

This study defines satisfaction as tourists' total evaluation on urban travel experience. It is based on multiple dimensions and we generalize humanity, landscape, construction, activity and total satisfaction as the items to measure satisfaction.

\subsection{Loyalty}

Tourists' loyalty to certain area means their revisit intention or recommendation intention to others (Chen \& Tsai, 2007). Revisit means tourists are satisfied with the travel destinations and they have the intention to revisit. It is 
their loyalty (Kozak, 2001). Sirdeshmukh et al. (2002) suggested that customer loyalty is diverse behavioral intention and it can avoid relationship risk and increase customers' trust and customers will show continuous loyal intention.

Gronholbt, Martensen \& Kristensen (2000) suggested that loyalty includes 4 dimensions: (1) repurchase intention; (2) intention to recommend the service or product to others; (3) tolerance of prices; (4) cross-purchase intention. Bigne et al. (2001) measured tourists' loyalty by customers' reaction, recommendation and revisit intention. Ingrid (2004) suggested that loyalty includes purchase of products and services by spending more money, recommendation to others and belief that it is worthy to purchase the product and service. Yoon \& Uysal (2005) measured tourists' loyalty by recommendation to relatives and friends and revisit. This study generalizes revisit intention, recommendation to others and residential intention upon loyalty proposed by the previous scholars as the items to measure loyalty.

\section{Research Hypotheses}

\subsection{Relationship between Tourism Image and Experiential Value}

Tourism image will influence tourists' expectation toward travel destinations and their concerns, selection and decision making of the spots (Birgit, 2001). Tourism image conveys value expectation to tourists and value is high-level abstract concept. It is consumers' overall evaluation on payment to products and perceived effectiveness of products or services. It means the trade-off between payment and acquisition (Zeithaml, 1988). Positive urban tourism image can create high value for tourists to travel in the city. Thus, tourism image should be feasible and with the budget, by image, it enhances tourists' perceived value ant attract tourists to visit the spots (Lawson \& Baud-Bovy, 1977). When tourists travel, they expect to acquire the experience from traveling to have positive impression. Their expectation is based on image of tourist spots and satisfaction with the travel activity and experience.

Research of Bigne et al. (2001) found that when tourists' tourism image is more positive, their comments on the quality of destinations are more positive. When tourism image is more positive, tourists' experiential value of destinations will increase (Fornell et al., 1996; Wu \& Zheng, 2014). Therefore, tourism image can enhance tourists' experiential value. Based on the above, this study proposes the hypothesis:

\section{H1: Tourism image of the city will significantly and positively influences tourists' experiential value.}

\subsection{Relationship between Innovation Marketing and Experiential Value}

Innovative product means to continuously improve attributes of products and increase new functions. Thus, they can satisfy consumers' needs. Thus, consumers' overall evaluation on function innovation, marketing technique innovation or service innovation will be higher than products without innovation. It can also increase customers' perceived value (Gallouj \& Weinstein, 1997). Service innovation means enterprises respond to customers' different needs by improving services in order to enhance customers' value perception (Jan \& Christian, 2005).

Rogers (1995) suggested that product innovation can enhance consumers' positive value. Horn \& Salvendy (2006) indicated that if we provide more information of innovative products to consumers, we will positively enhance consumers' experiential value. Based on the above, innovation positively influences customer value.

Regarding "city" in this study, the concept of product innovation can be applied to physical construction of cities. Service innovation can be applied to activity and procedure innovation. Therefore, this study infers that when the cities have innovation on software and hardware to develop innovative construction and activities, they will increase tourists' perceived value. Thus, this study proposes the hypothesis:

\section{H2: Innovation marketing of the city will significantly and positively influences tourists' experiential value.}

\subsection{Relationship between Tourism Image and Loyalty}

Tourism image has the functions of communication, promotion and marketing. Since image can establish specific target market, it can not only indicate the core market, but also enhance tourists' impression of the destinations. Therefore, many scholars treat tourism image as the decision-making variable of tourists' travel selection intention (Stabler, 1990; Cromption \& Ankomah, 1993). Tourism image is also the key factor of tourists' revisit intention of the spots. When tourists have more positive tourism image of the city, their preference to the city will be more significant and they will have the intention to visit or revisit the place (Wu \& Zheng, 2014; Court \& Lupton, 1997). When the city is selected as the destination, it usually shows strong and positive image to tourists (Alhemoud \& Armsrtong, 1996). Hence, tourism image directly or indirectly influences tourists' loyalty by experiential value and overall satisfaction (Prayag, 2008).

Bigne et al. (2001), Court \& Lupton (1997) suggested that the positive correlation between tourism image and 
revisit intention. It means that loyalty is influenced by both satisfaction and tourism image. Regardless of satisfaction with the spots, for individuals, the positive image of the spots will result in their revisit and recommendation intention. Therefore, effect of image on loyalty is important (Bosque \& Martin, 2008). Research of Chen \& Tsai (2007), Wang et al. (2009) and Yoon \& Uysal (2005) demonstrated the positive and significant relationship between tourism image and loyalty. When tourists have more positive image of destinations, their revisit intention will be higher (Rittichainuwat, Qu \& Brown, 2001). Based on the above, this study proposes the hypothesis:

\section{H3: Tourism image of the city will significantly and positively influences tourists' loyalty.}

\subsection{Relationship between Experiential Value and Satisfaction}

Tourists' experiential value is directly related to tourists' preference or selection. When tourists' experiential value is higher, tourists' satisfaction and revisit intention to the city will increase (Dodds \& Monroe, 1985). Bolton \& Drew (1991) found that when customers' experiential value is higher, satisfaction is also higher. Parasuraman, Zeithaml \& Berry (1996) suggested that higher experiential value enhances consumers' satisfaction. Pine \& Gilmore (1998) indicated that experiential value has positive and significant relationship with customer satisfaction and loyalty.

Based on research of Lee, Lee \& Wicks (2004), all kinds of experiential value positively influence customer satisfaction. Cronin, Brady \& Hult (2000) suggested that value influences customer satisfaction and customers' future behavioral intention. Tourists' experiential value of the spots and satisfaction will influence their revisit or intention to recommend it to others (Borrie \& Roggenbuck, 2001). Based on the above, experiential value positively influences satisfaction. Thus, this study proposes the hypothesis:

\section{H4: Tourists' experiential value will significantly and positively influence tourists' satisfaction.}

\subsection{Relationship between Satisfaction and Loyalty}

It is extremely important to measure tourists' satisfaction since there is close relationship between satisfaction and loyalty (Oliver, 1999; Wu \& Zheng, 2014). Petrick \& Backman (2002) demonstrated that antecedent variable of customers loyalty is customer satisfaction. According to many studies, satisfaction positively influences loyalty (Bosque \& Martin, 2008; Chi \& Qu, 2008; Wang et al., 2009; Wu \& Lin, 2014).

Klaus \& Maklan (2013), Pradhan \& Roy (2012), Christodoulides \& Michaelidou (2011) suggested that positive causal relation between customer satisfaction and customer loyalty. Customer satisfaction positively influences loyalty and satisfied customers will have positive word-of-mouth (Fornell, 1992). Lovelock \& Wright (2003) indicated positive correlation between customer satisfaction and customer loyalty. High customer satisfaction will lead to positive customers' word-of-mouth and result in high loyalty. Based on the above, satisfaction positively influences loyalty. Thus, this study proposes the hypothesis:

H5: Tourists' satisfaction will significantly and positively influence tourists' loyalty.

\subsection{Difference of the Cities}

In recent years, the cities in Taiwan start paying attention to development of urban tourism and they attempt to enhance urban economic development by tourism incomes. There are different features in different cities, such as National Palace Museum, Taipei 101, Yangmingshan National Park and Bei Tou hot spring in Taipei City; Taichung Park, Dajia Jenn Lann Temple, Fengjia Night Market and sun cake in Taichung City and Love Pier, Pier-2 Art Center, Meinung Folk Village, Ruifeng Night Market in Kaohsiung City. Natural environment, culture \& history, local snacks and marketing strategies in the cities are different. Thus, will tourists have different perceptions toward tourism image and innovation marketing strategies of different cities? What is the difference of the effect model of experiential value? It will rely on further study.

Therefore, this study treats Taipei City, Taichung City and Kaohsiung City as subjects and probes into effect of tourism image and innovation marketing strategy of the cities on tourists' experiential value, satisfaction and loyalty. It compares difference of the cities to probe into the similarity and difference. Thus, the hypothesis is proposed as follows:

H6: Different cities show significant differences in the path intensity of relationship models.

\section{Research Methodological}

\subsection{Research Framework}

This study treated tourism image and innovation marketing of the cities as independent variables and explored effects of tourism image and innovation marketing of cities on tourists' experiential value, satisfaction and 
loyalty. Different cities are moderators to distinguish tourist groups. This study then compared different group models. Based on previous literature review, this study constructs hypotheses and research framework. By questionnaire design and sampling survey and analysis, it validates hypotheses and the conceptual models proposed. Research framework is shown in Figure 1.

\subsection{Research Method}

This study first collected related theories and literatures as base of research framework and designed the draft of questionnaire which includes six parts. Part 1 is tourism image, Part 2 is innovation marketing, Part 3 is experiential value, Part 4 is satisfaction and Part 5 is loyalty. The previous scales are based on Likert 7-point scale. The scores are from "strongly disagree" (1) to "strongly agree" (7). Part 6 is background information and is measured by nominal scale.

\subsection{Pretest and Pilot}

In order to obtain effective measurement tools, before distributing formal questionnaires, this study modified questionnaires by pretest and pilot. In the pretest, by convenience sampling, it conducts in-depth interview on 20 tourists who have visited Taipei, Taichung, and Kaohsiung. According to findings, meanings of the items are clear and modification is not necessary.

By convenience sampling, this study selected 30 subjects from 3 cities as pilot samples, and conducted reliability and validity analysis on data of questionnaire. According to result of pilot questionnaire, Cronbach $\alpha$ of dimensions are higher than 0.7 (Nunnally, 1978) and item to total correlation coefficients are higher than 0.5 (Kerlinger, 1978). Thus, reliability of the dimensions is good. Based on result of EFA, eigenvalues of dimensions are higher than 1 and cumulative explained variation is higher than 0.5. Besides, factor loading of the variables are higher than 0.5 . Hence, the dimensions show convergent validity (Kaiser, 1958). We thus conduct the following formal survey by the questionnaire.

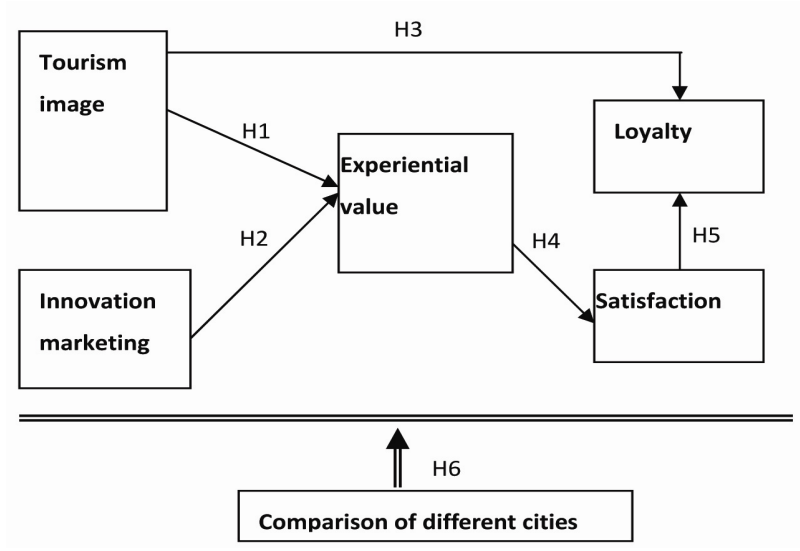

Figure 1. Research framework

\section{Research Results}

\subsection{Structure of Samples}

This study treated tourists (not local residents) who have visited Taipei, Taichung, and Kaohsiung in Taiwan as subjects and conducts convenience sampling by distributing questionnaires. A total of 260 questionnaires were respectively distributed to each city, totaling 780 questionnaires. After eliminating invalid questionnaires, there were 750 valid samples, including 249 from Taipei, 254 from Taichung, and 247 from Kaohsiung. The valid return rate was $96.15 \%$. According to analysis of samples, among all subjects, $50.0 \%$ are males and $50.0 \%$ are females. The majority is $25 \sim 34$ years old $(24.3 \%)$, followed by 35 44 years old (22.1\%). As to residential area, most of the subjects live in northern area (30.4\%), followed by southern area (29.9\%). As to educational level, university/college is the most $(61.1 \%)$ and the second is senior high school (vocational school) (21.3\%). Regarding occupation, the majority work in the service industry $(30.3 \%)$, and the second is student $(17.6 \%)$. The average monthly income is mostly 30,001 50,000 (34.9\%) and the second is $10,000-30,000(30.8 \%)$. The average visit is mostly once in a year $(39.7 \%)$, followed by once in less than half year (or half year) $(24.8 \%)$. As to cities visited, Taipei City is $33.2 \%$, Taichung City is $33.9 \%$ and Kaohsiung City is $32.9 \%$. According to respective analysis on 3 cities, distribution is similar to total samples. 


\subsection{Reliability and Validity Analysis of Questionnaire}

This study evaluated reliability and validity of 750 valid questionnaires by Cronbach $\alpha$, factor analysis and correlation analysis. According to Nunnally (1978), when Cronbach $\alpha$ is higher than 0.7, it is called high reliability. Kerlinger (1978) suggested that item to total correlation coefficient must be higher than standard 0.5. Thus, Cronbach $\alpha$ and correlation coefficient of dimensions in this study meets the standard. The overall reliability of questionnaire is good (see Table 3).

According to Kaiser (1958), eigenvalue of factors extracted by factor analysis must be higher than 1. Factor loading of variables must be higher than 0.5 and cumulative explained variation must be higher than 0.5 . Figures of the questionnaire are higher than the standard and thus, convergent validity of questionnaire in this study is good (see Table 1).

Based on suggestion of Gaski \& Nevin (1985), this study evaluated discriminant validity of dimensions in questionnaire (correlation coefficient of any two dimensions should be lower than Cronbach $\alpha$ of individual dimension), in order to test correlation coefficients of dimensions in this study. The result matches the previous standard. Hence, dimensions of questionnaire in this study have discriminant validity.

In addition, draft of the questionnaire of this study is based on foreign and domestic related literatures and scales as well as discussion and modification with scholars, experts and industries to establish pilot questionnaires. Finally, by pilot, we construct formal scale of questionnaire. Hence, content validity of questionnaire in this study is good. In addition, this study develops the research framework and model by theories and empirical studies of experts and scholars. It has nomological validity.

Table 1. Reliability and validity analysis of questionnaires

\begin{tabular}{|c|c|c|c|c|c|}
\hline Names of aspects and factors & $\begin{array}{l}\text { Item to total } \\
\text { correlation } \\
\text { coefficient }\end{array}$ & $\begin{array}{l}\text { Factor } \\
\text { loading }\end{array}$ & Eigenvalue & $\begin{array}{l}\text { Cumulative } \\
\text { explained } \\
\text { variation } \% \\
\end{array}$ & Cronbach $\alpha$ \\
\hline \multicolumn{6}{|l|}{ Tourism image } \\
\hline \multicolumn{6}{|l|}{ Natural ecology } \\
\hline There are beautiful landscapes in the city & 0.762 & 0.863 & \multirow{5}{*}{3.510} & \multirow{5}{*}{70.191} & \multirow{5}{*}{0.893} \\
\hline There are natural sceneries in the city & 0.781 & 0.872 & & & \\
\hline Climate of the city is comfortable. & 0.614 & 0.736 & & & \\
\hline There are many unique landscapes in the city & 0.765 & 0.858 & & & \\
\hline Ecological environment of the city is positive & 0.756 & 0.852 & & & \\
\hline \multicolumn{6}{|l|}{ Culture \& history } \\
\hline Featured old streets in the city & 0.783 & 0.866 & \multirow{5}{*}{3.780} & \multirow{5}{*}{75.601} & \multirow{5}{*}{0.919} \\
\hline Cultural relics with historic value in the city & 0.823 & 0.892 & & & \\
\hline Rich historic and cultural data in the city & 0.834 & 0.900 & & & \\
\hline Featured human atmosphere in the city & 0.802 & 0.876 & & & \\
\hline Well-known religious spots in the city & 0.713 & 0.810 & & & \\
\hline \multicolumn{6}{|l|}{ Urban environment } \\
\hline Transportation of the city is appropriate & 0.595 & 0.740 & \multirow{5}{*}{3.028} & \multirow{5}{*}{60.567} & \multirow{5}{*}{0.837} \\
\hline Diverse food service industries in the city & 0.646 & 0.786 & & & \\
\hline Hotels of the city are convenient & 0.621 & 0.774 & & & \\
\hline Public facilities in the city are complete & 0.687 & 0.816 & & & \\
\hline Road marks and signs of the city are clear & 0.634 & 0.773 & & & \\
\hline \multicolumn{6}{|l|}{ Local characteristics } \\
\hline Stores with traditional characteristics in the city & 0.633 & 0.768 & \multirow{5}{*}{3.159} & \multirow{5}{*}{63.185} & \multirow{5}{*}{0.854} \\
\hline Featured gifts in the city & 0.722 & 0.836 & & & \\
\hline Local featured spots in the city & 0.636 & 0.776 & & & \\
\hline Local featured food in the city & 0.728 & 0.840 & & & \\
\hline Local featured souvenirs in the city & 0.610 & 0.750 & & & \\
\hline \multicolumn{6}{|l|}{ Innovation marketing } \\
\hline \multicolumn{6}{|l|}{ Physical construction } \\
\hline $\begin{array}{l}\text { Buildings or streets with design characteristics in } \\
\text { the city }\end{array}$ & 0.742 & 0.886 & \multirow{3}{*}{2.413} & \multirow{3}{*}{80.442} & \multirow{3}{*}{0.878} \\
\hline Innovative public facilities in the city & 0.824 & 0.928 & & & \\
\hline Urban environment design of the city is innovative & 0.726 & 0.876 & & & \\
\hline
\end{tabular}




\begin{tabular}{|c|c|c|c|c|c|}
\hline Activity and procedure & & & & & \\
\hline $\begin{array}{l}\text { The city enhances urban image by frequent } \\
\text { activities }\end{array}$ & 0.716 & 0.837 & \multirow{4}{*}{3.026} & \multirow{4}{*}{75.653} & \multirow{4}{*}{0.892} \\
\hline Urban advertising of the city is impressive & 0.773 & 0.877 & & & \\
\hline $\begin{array}{l}\text { New marketing activities are often introduced in the } \\
\text { city }\end{array}$ & 0.808 & 0.899 & & & \\
\hline The city frequently holds attractive festivals & 0.756 & 0.866 & & & \\
\hline \multicolumn{6}{|l|}{ Experiential value } \\
\hline \multicolumn{3}{|l|}{ Affective experience } & \multirow{6}{*}{3.381} & \multirow{6}{*}{67.610} & \multirow{6}{*}{0.879} \\
\hline Traveling in the city releases my pressure & 0.717 & 0.841 & & & \\
\hline Traveling in the city is pleasant & 0.777 & 0.878 & & & \\
\hline Traveling in the city is relaxing & 0.697 & 0.815 & & & \\
\hline Friendliness is perceived when I travel in the city & 0.621 & 0.743 & & & \\
\hline Atmosphere in the city is stimulating & 0.732 & 0.829 & & & \\
\hline \multicolumn{6}{|l|}{ Sensory experience } \\
\hline $\begin{array}{l}\text { By traveling in the city, I experience local featured } \\
\text { landscapes }\end{array}$ & 0.703 & 0.823 & \multirow{5}{*}{3.221} & \multirow{5}{*}{64.414} & \multirow{5}{*}{0.861} \\
\hline $\begin{array}{l}\text { By traveling in the city, I appreciate natural } \\
\text { sceneries }\end{array}$ & 0.709 & 0.828 & & & \\
\hline By traveling in the city, I learn local culture & 0.706 & 0.824 & & & \\
\hline By traveling in the city, I taste local featured snacks & 0.649 & 0.774 & & & \\
\hline By traveling in the city, I experience the novelty & 0.631 & 0.761 & & & \\
\hline \multicolumn{6}{|l|}{ Quality experience } \\
\hline Historic relics of the city are maintained properly & 0.717 & 0.816 & \multirow{5}{*}{3.708} & \multirow{5}{*}{74.161} & \multirow{5}{*}{0.913} \\
\hline Public facilities of the city are excellent & 0.768 & 0.853 & & & \\
\hline Travel environment of the city is clean & 0.805 & 0.881 & & & \\
\hline Hygiene of diet in the city is positive & 0.805 & 0.881 & & & \\
\hline Appearance of the city is maintained properly & 0.793 & 0.873 & & & \\
\hline \multicolumn{6}{|l|}{ Satisfaction } \\
\hline Tourism resources are rich in the city & 0.552 & 0.693 & \multirow{6}{*}{3.613} & \multirow{6}{*}{60.220} & \multirow{6}{*}{0.866} \\
\hline $\begin{array}{l}\text { I have good memory about the tourist spots in the } \\
\text { city }\end{array}$ & 0.623 & 0.747 & & & \\
\hline Local people of the city are often friendly & 0.566 & 0.689 & & & \\
\hline Travel consultation service of the city is satisfying & 0.687 & 0.792 & & & \\
\hline Overall environment of the city is satisfying & 0.791 & 0.877 & & & \\
\hline Overall atmosphere of the city is pleasant & 0.732 & 0.840 & & & \\
\hline \multicolumn{6}{|l|}{ Loyalty } \\
\hline I have high intention to revisit the city & 0.731 & 0.859 & \multirow{4}{*}{2.930} & \multirow{4}{*}{73.251} & \multirow{4}{*}{0.877} \\
\hline I recommend the city to relatives and friends & 0.766 & 0.883 & & & \\
\hline I share advantages of the city to others & 0.791 & 0.889 & & & \\
\hline In my next trip, I will treat the city as the priority & 0.646 & 0.789 & & & \\
\hline
\end{tabular}

\subsection{Confirmatory Factor Analysis}

In order to validate the efficiency of dimensions, this study conducted Confirmatory Factor Analysis (CFA) on tourism image, innovation marketing, experiential value, satisfaction and loyalty by AMOS.

According to precise principle, fit measures of measurement model should be based on ratio between chi-square and freedom $<3$ (Carmines \& MacIver, 1981), RMSEA $<0.05$ and GFI, AGFI, NFI, RFI and CFI $>0.9$ (Bagozzi \& Yi, 1988; Joreskog \& Sorbom, 1989). The result shows that among fit measures of measurement model, $\chi^{2 /} \mathrm{df}$ is 1.575 , RMSEA is 0.028 , GFI is 0.788 , AGFI is 0.750 , NFI is 0.847 , RFI is 0.827 and CFI is 0.937 . The previous results match or are close to the standard. Hence, the indicators have construct validity and measurement efficiency.

\subsection{Competing Model Analysis}

According to different cities, this study clusters tourists into Taipei City (249 people), Taichung City (254 people) and Kaohsiung City (247 people). By AMOS, this study conducted linear structural competing model in order to recognize causal relation and correlation among the variables. According to analytical result, the fit of the model is shown below: $\chi 2$ /df is 1.608 , RMSEA is 0.029 , GFI is 0.781 , AGFI is 0.746 , NFI is 0.842 , RFI is 0.823 and 
CFI is 0.933 . The result matches or is close to good model. Therefore, fit of the competition model of this study is good. The model is acceptable.

\subsection{Relation path Comparison of Three Cities}

According to path analysis of dimensions, relation paths of three groups are different:

In path of tourism image of Taipei, Taichung, and Kaohsiung on experiential value, there is positive and significant effect. The result supports $\mathrm{H} 1$; in path of innovation marketing of Taipei and Taichung on experiential value, there is positive and significant effect. Kaohsiung does not show significant effect. The result partially supports $\mathrm{H} 2$; only tourism image of Taichung positively and significantly influences loyalty in the path and Taipei and Kaohsiung does not show significant effects. The result partially supports H3; in the path of experiential value of Taipei, Taichung, and Kaohsiung on satisfaction, it is positive and significant. The result supports H4; in the path of satisfaction of Taipei, Taichung, and Kaohsiung on loyalty, there is positive and significant effect. The result supports H5. Analytical result of model is shown in Table 2.

According to different cities, this study compares the intensity of effects of paths (see Table 2):

(1) According to effect of "tourism image" on "experiential value", with pair comparison of Taipei, Taichung, and Kaohsiung, the relation paths show significant difference. According to result of $t$ test, effect of Kaohsiung City in the path is more significant.

(2) According to analysis of effect of "innovation marketing" on "experiential value": Taipei and Kaohsiung and Taichung and Kaohsiung show significant difference in the relation path. Based on result of $t$ test, effect of Taipei is more significant.

(3) According to effect of "tourism image" on "loyalty": Taichung and Kaohsiung are significantly different in the relation path. Based on result of $t$ test, effect of Taichung is more significant.

(4) According to effect of "experiential value" on "satisfaction": Taipei, Taichung, and Kaohsiung do not show significant difference in the relation path. Based on effect coefficients, effects of three cities in the path are significant.

(5) According to analysis of effect of "satisfaction" on "loyalty": Taipei, Taichung, and Kaohsiung have significant difference in the relation path. According to result of $t$ test, effect of Kaohsiung is more significant in the path.

Based on the above, with the comparison of relation models of different cities, intensity of tourism image and innovation marketing on experiential value, satisfaction and loyalty is significantly different because of different cities. Hence, H6 is partially supported.

Table 2. The differences in the intensity of path relations between different cities

\begin{tabular}{|c|c|c|c|c|c|c|c|}
\hline \multirow[b]{2}{*}{ Path relations } & \multicolumn{3}{|c|}{ Standardized Regression Weights } & \multicolumn{4}{|l|}{ T value } \\
\hline & Taipei (249) & Taichung (254) & $\begin{array}{l}\text { Kaohsiung } \\
\text { (247) }\end{array}$ & $\begin{array}{l}\text { Taipei vs. } \\
\text { Taichung }\end{array}$ & $\begin{array}{l}\text { Taipei vs. } \\
\text { Kaohsiung }\end{array}$ & $\begin{array}{l}\text { Taichung } \\
\text { Kaohsiung }\end{array}$ & vs. \\
\hline $\begin{array}{l}\text { H1: Tourism image } \rightarrow \\
\text { Experiential value }\end{array}$ & $0.113 *$ & $0.484 * * *$ & $0.895 * * *$ & $3.192 * *$ & $4.420 * *$ & $3.101 * *$ & \\
\hline $\begin{array}{l}\text { H2: Innovation marketing } \\
\rightarrow \text { Experiential value }\end{array}$ & $0.793 * * *$ & $0.463 * * *$ & 0.046 & -0.068 & $-3.176 * *$ & $-2.457^{*}$ & \\
\hline $\begin{array}{l}\text { H3: Tourism image } \rightarrow \\
\text { Loyalty }\end{array}$ & 0.097 & $0.208^{*}$ & -0.107 & 1.443 & -1.557 & $-2.194 *$ & \\
\hline $\begin{array}{l}\text { H4: Experiential value } \rightarrow \\
\text { Satisfaction }\end{array}$ & $0.879 * * *$ & $0.730^{* * *}$ & $0.845^{* * *}$ & -0.999 & 0.439 & 1.288 & \\
\hline $\begin{array}{l}\text { H5: Satisfaction } \rightarrow \\
\text { Loyalty }\end{array}$ & $0.781 * * *$ & $0.336^{* * *}$ & $0.893 * * *$ & $-2.110 *$ & 2.186* & $3.405^{* *}$ & \\
\hline
\end{tabular}

$*: \mathrm{P}<0.05 ; * *: \mathrm{P}<0.01 ; * * *: \mathrm{P}<0.001$.

\section{Conclusions and Recommendations}

\subsection{Conclusions and Discussion}

From perspective of tourists, this study focused on 3 major cities in Taiwan and conducted empirical study to explore the relationship between tourism image and innovation marketing of the cities and tourists' experiential 
value, satisfaction and loyalty. It compared the correlation models of different cities. The conclusions are as follows:

(1) Effect of tourism image of cities on experiential value:

Tourism image of Taipei, Taichung, and Kaohsiung significantly and positively influences experiential value. The result matches the perspective of Bigne et al.(2001), Wu \& Zheng et al.(2014). Hence, when tourists have high identification with natural ecology, culture \& history, urban environment and local characteristics of Taipei, Taichung, and Kaohsiung, it could enhance their experiential value to travel in the city. Thus, with positive tourism image of the cities, tourists can obtain good memory from the experience and create better perception value. Thus, tourism image of the cities is extremely important.

(2) Effect of innovation marketing of cities on experiential value:

Innovation marketing strategy of Taipei and Taichung significantly and positively influences experiential value. The result matches the concepts of Jan \& Christian (2005), Horn \& Salvendy et al. (2006). It means that when tourists are identified with innovation marketing, which can directly respond to diverse needs, it can enhance tourists' experiential value. In other words, innovation marketing strategy of the cities positively enhances tourists' experiential value. However, innovation marketing strategy of Kaohsiung City does not significantly influence experiential value. We infer that in comparison to innovation marketing strategies of Taipei and Taichung, those in Kaohsiung City are not attractive for tourists. Thus, they cannot enhance tourists' experiential value. Match between innovation marketing strategy and tourists' needs is the issue for further study.

(3) Effect of tourism image of cities on loyalty:

Among 3 cities, only tourism image of Taichung significantly and positively influences loyalty. It means that for tourists of Taichung, the perceived culture and local characteristics can highly enhance tourists' interest and they have the intention to revisit. However, tourism image of Taipei and Kaohsiung on loyalty is significant. We infer that the image of Kaohsiung is usually associated with pollution and Taipei is crowded with traffic jam. It lowers tourists' revisit intention. Therefore, it is extremely important to reconstruct urban image.

(4) Effect of tourists' experiential value on satisfaction:

Experiential value of tourists in Taipei, Taichung, and Kaohsiung significantly and positively influences satisfaction. The result matches the concepts of Lee, Lee \& Wicks (2004), Borrie \& Roggenbuck et al.(2001). It means that tourists' needs can be satisfied by traveling in the city. They acquire knowledge and experience and increase perception value of tourists' experience. Tourists will be satisfied.

(5) Effect of tourists' satisfaction on loyalty:

Tourists' satisfaction in 3 cities significantly and positively influences loyalty. The result matches the concept of Klaus \& Maklan (2013) and Pradhan \& Roy et al. (2012). It means that once tourists are satisfied with the travel experience in the cities, they will have positive word-of-mouth, be loyal and have revisit intention and revisit intention. Thus, satisfaction is the key factor of tourists' loyalty.

(6) According to comparison of correlation models of different cities:

(a) As to path intensity of tourism image on experiential value, effect of Kaohsiung is the most significant. It shows that when tourists identify with tourism image of Kaohsiung, it will strongly enhance tourists' value perception. For Kaohsiung City, construction of positive urban image is the most effective measure.

(b) As to path intensity of innovation marketing on experiential value, effect of Taipei is the most significant. Thus, Taipei is more popular of tourists in innovation marketing strategy. It draws tourists' attention and the value perception is higher.

(c) As to path intensity of tourism image on loyalty, effect of Taichung is the most significant. Hence, revisit intention to tourists attracted by tourism image of Taichung is the highest.

(d) As to path intensity of experiential value on satisfaction, effects of 3 cities are significant. It means that tourists' experiential value to travel in different cities significantly enhances satisfaction.

(e) As to path intensity of satisfaction on loyalty, effect of Kaohsiung is the highest. It means that satisfaction of tourists of Kaohsiung is the most likely to establish loyalty.

Based on the above, the cities are different and they should establish their characteristics to attract more tourists.

\subsection{Managerial Implication}

According to empirical analysis, this study explored tourists' perception of tourism image and innovation 
marketing of cities and establishes the correlation model of experiential value, satisfaction and loyalty. The finding can serve as reference for the cities:

\section{(1) Construction of unique urban image:}

According to research findings, path from tourism image to tourists' experiential value, satisfaction and loyalty shows positive and significant relationship. Thus, when tourists' perceived tourism image is more positive and tourists' experiential value is higher, satisfaction and loyalty will be higher. We suggest that the cities should demonstrate tourism attraction by specific history, humanity and nature in order to promote the cities, emphasize local characteristics and culture, and increase the history background of the spots. Therefore, they will establish unique tourism image for tourists.

In the past, in marketing of the cities in Taiwan, tourism image is not emphasized. Therefore, tourism characteristics are not significant. Using other countries as examples, Hong Kong is the paradise of food and shopping. New York is American spirit and global cultural center. Paris demonstrates the freedom, culture, art and taste of life. Beijing is the capital of Chinese traditional culture. The style and tourism image of these important cities are strong and the positions are specific. Thus, they can attract the tourists by proper marketing strategies in order to promote the spots and increase tourism incomes. Therefore, construction of unique urban image is the priority of urban tourism development.

(2) Innovation is the factor of sustainable development of tourism industry:

According to findings, innovation marketing strategy of Taipei City and Taichung City significantly and positively influences experiential value. Thus, when tourists perceive high degree of urban innovation marketing, their experiential value will be more significant. Nowadays, experience is important. Thus, the cities should plan more diverse and different innovation marketing strategies in order to draw tourists' attention. For instance, the local governments and residents should actively protect local natural resources local characteristics, promote local travel resources and have increased communication with external world. By internet, they diffuse the information. The residents and industries are the principal participants to promote the spots. They make efforts for the urban development and fulfill the concept of urban tourism. It will thus strengthen tourists' experience and perception.

Thus, the cities should design featured marketing activities to satisfy tourists' profound needs and increase their value perception.

\section{(3) Experiential value which surpasses tourists' satisfaction:}

Experiential value positively influences customer satisfaction and satisfaction also positively influences loyalty. It means that when tourists experience higher value in the traveling and satisfaction is higher, loyalty will be more significant. Therefore, the cities should transform experiential value into satisfaction. Thus, it will be out of tourists' expectation and tourists' satisfaction will become loyalty.

It is consumer-oriented era. It is necessary to value tourists' needs and listen to them. We respond to tourists' needs or actively provide travel information. It will enhance their satisfaction and the position of the city for them. It will not only keep the tourists, but also enhance the reputation and new tourists by old tourists' promotion. We can reinforce marketing by positive word-of-mouth. Therefore, the cities can obtain new tourists without paying extra costs. It will also enhance competitiveness and economic benefits of the cities. Thus, experiential value and satisfaction are strategic tools to enhance tourists' revisit and recommendation intention.

Empirical result of this study on 3 cities of Taiwan can serve as the reference to other cities and we provide useful information and suggestions to help them plan appropriate marketing and tourism strategies. Regarding tourism resources of the cities, different cultural backgrounds, development, local characteristics and national characteristics determine the images of the cities. History, art, shopping, activities, performance, new construction and artificial facilities can be the marketing tools for the cities. Thus, the cities can adopt unique tourism image and innovation marketing to maintain tourists' positive comments on the cities and enhance their revisit intention.

\subsection{Research Limitations and Future Studies Recommendations}

Conceptual framework and empirical result of this study can provide new perspectives as the reference of the following research. However, the following problems should be improved:

(1) Population of this study is tourists who have visited Taipei, Taichung, and Kaohsiung. Although the research finding has demonstrated some common points, there is difference. Thus, the researcher findings cannot be applied to all cities since local characteristics and humanity of the cities are different and the findings can be 
various. We suggest that future researchers can explore different types of cities, such as big cities and townships and compare them in order to explore the application and outcome of the models in this study in different cities. The conceptual framework of this study can be more universal.

(2) By competition model, this study compares correlation model of tourism image, innovation marketing, experiential value, satisfaction and loyalty of 3 cities. We suggest that future researchers can increase other variables to explore tourists' views on issues related to urban tourism industry and the research dimensions will be more complete.

\section{References}

Afuah, A. (2003). Innovation Management: Strategies, Implementation, and Profits. NY: Oxford University Press.

Alhemoud, A. M., \& Armsrtong, E. G. (1996). Image of tourism attraction in Kuwait. Journal of Travel Research, 34(4), 76-80.

Bagozzi, R. P., \& Yi, Y. (1988). On the evaluation of structure equations models. Academic of Marketing Science, 16(1), 76-94.

Baker, K. A., \& Crompton, J. L. (2000). Quality, satisfaction and behavioral intentions. Annals of Tourism Research, 27(3), 785-804.

Betz, F. (1998). Strategic Technology Management. NY: Mc Graw-Hill.

Bigne, J. E., Sanchez, M. I., \& Sanchez, J. (2001). Tourism image, evaluation, variables, and after purchase behavior: Interrelationship. Tourism Management, 22(6), 607-616. http://dx.doi.org/10.1016/S0261-5177(01)00035-8

Birgit, L. (2001). Image segmentation: The case of a tourism destination. Journal of services marketing, 15(1), 49-66. http://dx.doi.org/10.1108/08876040110381517

Bolton, R. N., \& Drew, J. H. (1991). A longitudinal analysis of the impact of service changes on customer attitudes. Journal of Marketing, 55, 1-9.

Borrie, W. T., \& Roggenbuck, J. (2001). The dynamic, emergent, and multi-phasic nature of on-site wilderness experiences. Journal of Leisure Research, 33(2), 202-228.

Bosque, I. R., \& Martin, H. S. (2008). Tourist satisfaction: A cognitive-affective model. Annals of Tourism Research, 35(2), 551-573.

Carmines, E. G., \& Maclver, J. P. (1981). Analyzing models with unobserved variables. In G. W. Bohrnstedt \& E. F. Borgatta (Eds.), Social Measurement: Current Issues (pp. 65-115). CA: Sage Publications.

Carpenter, M. (2009). Just how joint is joint action in infancy? Topics in Cognitive Science, 1(2), 380-392. http://dx.doi.org/10.1111/j.1756-8765.2009.01026.x

Castro, C. B., Armario, E. M., \& Ruiz, D. M. (2007). The influence of market heterogeneity on the relationship between a destination's image and tourists' future behaviour. Tourism Management, 28(1), 175-187.

Catherine, L. W., \& Pervaiz, K. A. (2004). The development and validation of the organizational innovativeness construct using confirmatory factor analysis. European Journal of Innovation Management, 7(4), 303-313. http://dx.doi.org/10.1108/14601060410565056

Certo, S. C. (2003). Modern Management. NJ: Prentice Hall.

Chaudhary, M. (2000). India's image as a tourist destination-A perspective of foreign tourists. Tourism management, 21, 293-297. http://dx.doi.org/10.1016/S0261-5177(99)00053-9

Chen, C. F., \& Tsai, D. C. (2007). How destination image and evaluative factors affect behavioral intentions? Tourism Management, 8(4), 1115-1122.

Chen, K. M., \& Liu, R. J. (2005). Interface strategies in modular product innovation. Technovation, 25(7), 771-782. http://dx.doi.org/10.1016/j.technovation.2004.01.013

Chi, C. G. Q., \& Qu, H. (2008). Examining the structural relationships of destination image, tourist satisfaction and destination loyalty: An integrated approach. Tourism Management, 29, 624-636.

Christodoulides, G., \& Michaelidou, N. (2011). Shopping motives as antecedents of e-satisfaction and e-loyalty. Journal of Marketing Management, 27(1-2), 181-197. http://dx.doi.org/10.1080/0267257X.2010.489815

Cole, S. T., \& Scott, D. (2004). Examining the mediating role of experience quality in a model of tourist 
experience experiences. Journal of Travel \& Tourism Marketing, 16(1), 70-90.

Court, B., \& Lupton, R. A. (1997). Customer portfolio development: Modeling destination adopters, inactive, and rejecters. Journal of Travel Research, 36(1), 35-43. http://dx.doi.org/10.1177/004728759703600106

Cromption, J. L., \& Ankomah, P. K. (1993). Choice set proposition in destination decisions. Annals of Tourism Research, 20, 18-23.

Cronin, J. J. Jr., Brady, M. K., \& Hult, G. T. (2000). Assessing the effects of quality, value, and customer satisfaction on customer behavioral intentions in service environments. Journal of Retailing, 76(2), 193-218.

Dodds, W. B., \& Monroe, K. B. (1985). The effects of brand and price information on subjective product evaluations. In E. C. Hirschman \& M. B. Holbrook (Eds.), Advances in Consumer Research (Vol. 12, pp. 85-90). Provo, Utah: Association for Consumer Research.

Echtner, C. M., \& Ritchie, J. R. B. (1993). The measurement of destination image: An empirical assessment. Journal of Travel Research, 31(4), 3-13. http://dx.doi.org/10.1177/004728759303100402

Fakeye, P. C., \& Crompton, J. L. (1991). Image differences between prospective, first-time, and repeat visitors to the lower Rio Grande valley. Journal of Travel Research, 30(2), 10-16. http://dx.doi.org/10.1177/004728759103000202

Flint, D. J., Woodruff, R. B., \& Gardial, S. F. (2002). Exploring the phenomenon of customers' desired value change in a business-to-business context. Journal of Marketing, 66(4), 102-117.

Fornell, C. (1992). A national customer satisfaction barometer: The Swedish experience. Journal of Marketing, 56(1), 6-21.

Fornell, C., Johnson, M. D., Anderson, E. W., Cha, J., \& Bryant, B. E. (1996). The American customer satisfaction index: Nature, purpose, and findings. Journal of Marketing, 60(4), 7-18.

Gallarza, M. G., \& Saura, I. G. (2006). Value dimensions, perceived value, satisfaction and loyalty: An investigation of university students' travel behaviour. Tourism Management, 27, 437-452.

Gallouj, F., \& Weinstein, O. (1997). Innovation in services. Research Policy, 26, 537-556.

Gaski, J. F., \& Nevin, J. R. (1985). The differential effects of exercised and unexercised power sources in a marketing channel. Journal of Marketing Research, 22, 130-142.

Gronholbt, L., Martensen, A., \& Kristensen, K. (2000). The relationship between customer satisfaction and loyalty: Cross-industry differences. Total Quality Management, 11, 509-516.

Gunn, C. A., \& Var, T. (2002). Tourism Planning: Basics, Concept, Cases. New York: Routledge.

Hellier, P. K., Geursen, G. M., Carr, R. A., \& Rickard, J. A. (2003). Customer repurchase intention: A general structural equation model. European Journal of Marketing, 37(11/12), 1762-1800.

Horn, D., \& Salvendy, G. (2006). Consumer-based assessment of product creativity: A review and reappraisal. Human Factors and Ergonomics in Manufacturing, 16(2), 155-175. http://dx.doi.org/10.1002/hfm.20047

Hosany, H., Ekinci, Y., \& Uysal, M. (2006). Destination image and destination personality: An application of branding theories to tourism places. Journal of Business Research, 59, 638-642.

Ingrid, F. (2004). An index method for measurement of customer satisfaction. The TQM Magazine, 16(1), 57-66. http://dx.doi.org/10.1108/09544780410511498

Jan, V., \& Christian, Z. (2005). Introduction: Innovation in services. Industry and Innovation, 12(2), 147-152.

Johannessen, J. A., Olsen, B., \& Lumpkin, G. T. (2001). Innovation as newness: What is new, how new, and new to whom? European Journal of Innovation Management, 4(1), 20-31. http://dx.doi.org/10.1108/14601060110365547

Joreskog, K. G., \& Sorbom, D. (1989). LISREL 7 User's Reference Guide. Chicago: Scientific Software.

Kaiser, H. F. (1958). The varimax criterion for analysis rotation in factor analysis. Psychometrika, 23, 187-200.

Kerlinger, F. N. (1978). Foundation of Behavioral Research. NY: McGraw-Hill.

Kim, M. K., Park, M. C., \& Jeong, D. H. (2004). The effects of customer satisfaction and switching barrier on customer loyalty in Korean mobile telecommunication services. Telecommunications Policy, 28, 145-149.

Klaus, P., \& Maklan, S. (2013). Towards a better measure of customer experience. International Journal of 
Market Research, 55(2), 227-246.

Kozak, M. (2001). Repeaters behavior at two distinct destination. Annals of Tourism Research, 28(3), 784-807.

Lawson, F., \& Baud-Bovy, M. (1977). Tourism and Recreational Development. London: Architectural Press.

Lee, C. K., Lee, Y. K., \& Wicks, B. E. (2004). Segmentation of festival motivation by nationality and satisfaction. Tourism Management, 25(1), 61-70.

Lee, J., Graefe, A. R., \& Burns, R. C. (2004). Service quality, satisfaction, and behavioral intention among forest visitors. Journal of Travel \& Tourism Marketing, 17(1), 73-82.

Leisen, B. (2001). Image segmentation: The case of a tourism destination. Journal of Services Marketing, 15(1), 49-66. http://dx.doi.org/10.1108/08876040110381517

Lovelock, C. H., \& Wright, L. K. (2003). Principles of Service Marketing and Management. NJ: Prentic-Hall.

Martin, H. S., \& del Bosque, I. A. R. (2008). Exploring the cognitive-affective nature of destination image and the role of psychological factors in its formation. Tourism Management, 29(2), 263-277.

Mathwick, C., Malhotra, N. K., \& Rigdon, E. (2002). The effect of dynamic retail experiences on experiential perceptions of value: An Internet and catalog comparison. Journal of Retailing, 78(1), 51-60.

Mayo, E. J., \& Jarvis, L. P. (1981). Psychology of Leisure Travel. Boston: CBI.

Nunnally, J. C. (1978). Psychometric Theory. NY: Mcgraw-Hill.

Oliver, R. L. (1999). Whence consumer loyalty. Journal of Marketing, 63(4), 33-44.

Ottenbacher, M., \& Gnoth, J. (2005). How to develop successful hospitality innovation. Cornell Hotel and Restaurant Administration Quarterly, 46(2), 205-222.

Pappu, R., \& Quester, P. (2006). Does customer satisfaction lead to improved brand equity? An empirical examination of two categories of retail brands. The Journal of Product and Brand Management, 15(1), 4-14. http://dx.doi.org/10.1108/10610420610650837

Parasuraman, A., Zeithaml, V. A., \& Berry, L. L. (1996). The behavioral consequence of service quality. Journal of Marketing, 60, 31-46.

Petrick, J. F., \& Backman, S. J. (2002). Experience use history as a segmentation tool to examine golf travelers' satisfaction, perceived value and repurchase intentions. Journal of Vacation Marketing, 8(4), 351-357.

Pine II, B. J., \& Gilmore, J. H. (1998). Welcome to the experience economy. Harvard Business Review, 76(4), 97-105.

Pine II, B. J., \& Gilmore, J. H. (2003). The Experience Economy. Cite Publishing Ltd.

Pradhan, S., \& Roy, S. (2012). Determinants of satisfaction and loyalty in apparel retailing. International Journal of Business Insights \& Transformation, 5(1), 78-86.

Prayag, G. (2008). Image, satisfaction and loyalty-the case of Cape Town. An International Journal of Tourism and Hospitality Research, 19(2), 205-224.

Prebensen, N. K. (2007). Exploring tourists' images of a distant destination. Tourism management, 28(3), 747-756.

Reisinger, Y., \& Turner, L. W. (2003). Cross-Cultural Behaviour in Tourism: Concepts and Analysis. Oxford: Butterworth-Heinemann.

Ritchie, J. B., \& Crouch, G. I. (2000). The competitive destination: A sustainability perspective. Tourism Management, 21, 1-7.

Rittichainuwat, B. N., Qu, H., \& Brown, T. (2001). Thailand's international travel image. Cornell Hotel and Restaurant Administration Quarterly, 42(2), 82-95.

Rogers, E. M. (1995). Diffusion of Innovations. NY: The Free Press.

Ross, G. F. (1993). Ideal and actual images of backpacker visitors to northern Australia. Journal of Travel Research, 32(2), 54-57. http://dx.doi.org/10.1177/004728759303200208

Royo-Vela, M. (2009). Rural-cultural excursion conceptualization: A local tourism marketing management model based on tourism destination image measurement. Tourism Management, 30(3), 419-428.

Schmitt, B. H. (1999). Experiential marketing. Journal of Marketing Management, 15(1), 53-67. 
Sirdeshmukh, D., Singh, J., \& Sabol, B (2002). Consumer trust, value, and loyalty in relational exchanges. Journal of Marketing, 66(1), 15-37.

Smith, B. (1998). Buyer-seller relationships: Bonds, relationship management, and sex-type. Canadian journal of administrative sciences, 15(1), 76-92. http://dx.doi.org/10.1111/j.1936-4490.1998.tb00153.x

Smith, J. B., \& Colgate, M. (2007). Customer value creation: A practical framework. Journal of Marketing Theory and Practice, 15(1), 7-23.

Stabler, M. (1990). The concept of opportunity sets as a methodological framework for the analysis of selling tourism places: the industry view. In G. Ashworth \& B.Goodall (Eds.), Marketing Tourism Places (pp. 23-41). London: Routledge.

Stepchenkova, S., \& Morrison, A. M. (2008). Russia's destination image among American pleasure travelers: Revisiting echtner and ritchie. Tourism Management, 29(3), 548-560. http://dx.doi.org/10.1016/j.tourman.2007.06.003

Sweeney, J. C., \& Soutar, G. N. (2001). Consumer perceived value: The development of a multiple item scale. Journal of Retailing, 77(2), 203-220. http://dx.doi.org/10.1016/S0022-4359(01)00041-0

Ulaga, W. (2003). Capturing value creation in business relationships a customer perspective. Industrial marketing Management, 32(8), 677-693. http://dx.doi.org/10.1016/j.indmarman.2003.06.008

Vargo, S. L., \& Lusch, R. F. (2006). Service-dominant logic: What it is, what it is not, what it might be. In R. F. Lusch \& S. L. Vargo (Eds.), The Service-Dominant Logic of Marketing: Dialog, Debate and Directions (pp. 43-56). Armonk, NY: M.E Sharpe, Inc.

Wang, X., Zhang, J., Gu, C. L., \& Zhen, F. (2009). Examining antecedents and consequences of tourist satisfaction: A structural modeling approach. Tsinghua Science and Technology, 14(3), 397-406.

Williams, P., \& Soutar, G. N. (2009). Value, satisfaction, and behavioral intentions in an adventure tourism context. Annals of Tourism Research, 36(3), 413-438. http://dx.doi.org/10.1016/j.annals.2009.02.002

Wu, S. I., \& Lin, T. R. (2014). The influence of relational bonds and innovative marketing on consumer perception-A study of theme parks. Journal of Management and Strategy, 5(4), 54-67.

Wu, S. I., \& Zheng, Y. H. (2014). The influence of tourism image and activities appeal on tourist loyalty-A study of Tainan City in Taiwan. Journal of Management and Strategy, 5(4), 121-135.

Xi, F., \& Fang, L. (2005). Commentary of Schumpeter's innovation theory. China Economist, 19(7), 27-28.

Yang, H. E., Wu, C. C., \& Wang, K. C. (2009). An empirical analysis of online game service satisfaction and loyalty. Expert Systems with Applications, 36, 1816-1825. http://dx.doi.org/10.1016/j.eswa.2007.12.005

Yoon, Y., \& Uysal, M. (2005). An examination of the effects of motivation and satisfaction on destination loyalty: A structural model. Tourism Management, 26(1), 45-56.

Zeithaml, V. A. (1988). Consumer perceptions of price, quality, and value: A means-end model and synthesis of evidence. Journal of Marketing, 52, 2-22.

\section{Copyrights}

Copyright for this article is retained by the author(s), with first publication rights granted to the journal.

This is an open-access article distributed under the terms and conditions of the Creative Commons Attribution license (http://creativecommons.org/licenses/by/3.0/). 